\title{
State Immunity and the Execution of Investment Arbitration Awards
}

\section{A Review of the Plea of State Immunity and the Execution of Investment Arbitration Awards from the Viewpoint of the Forum State}

\author{
Phoebe D. Winch
}

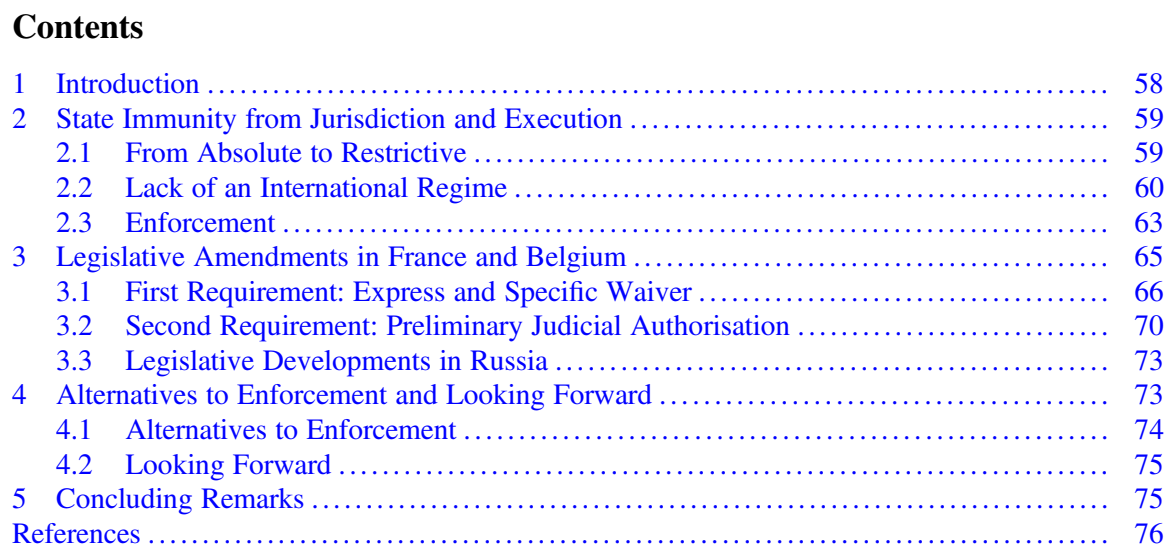

\begin{abstract}
The doctrine of state immunity occupies a fundamental place in international law. The application of the doctrine, largely left to the national laws of states, is not consistent. One particular area of inconsistency is the treatment of the plea of state immunity from execution of arbitral awards resulting from investor-state disputes. The issue of state immunity from execution has come to the fore in light of a number of recent attempts by award-creditors to attach their awards against the assets of a foreign state located in jurisdictions considered to be
\end{abstract}

\footnotetext{
Any views expressed in this chapter are personal in nature and do not necessarily reflect the view of the author's employer or any organisations with which the author is presently or has in the past been affiliated.

I would like to extend my gratitude and sincere thanks to Prof. Chester Brown for his continued and invaluable support, including in the drafting of this chapter.
}

\section{P. D. Winch (ه)}

Office of International Law, Attorney-General's Department, Canberra, ACT, Australia 
"pro-enforcement", such as France and Belgium. This chapter considers the plea of state immunity and the execution of investment arbitration awards from the perspective of the forum state. In particular, it addresses the introduction of procedural and substantive amendments to French and Belgian laws on state immunity following these attempts by award-creditors to seize foreign state assets located in their respective jurisdictions. The chapter posits a way forward for investors seeking to navigate the landscape governing state immunity from execution.

\section{Introduction}

The doctrine of state immunity occupies a fundamental place in international law and international relations, enabling the state and its representatives to fulfil essential public functions. ${ }^{1}$ The character of state immunity as an established rule of international law has been recognised by both civil and common law jurisdictions, and "adopted as a general rule of customary international law solidly rooted" in state practice. ${ }^{2}$ As will be explored in this chapter, the application of the doctrine is largely left to each state's national laws, as there is no single international regime in force governing state immunity. In practice, this has resulted in a lack of uniformity in the application of the rules of state immunity as between states, as well as in the internal jurisprudence of states.

One particular area of inconsistency, which is the focus of this chapter, is in the treatment of the plea of state immunity from execution of arbitral awards resulting from investor-state disputes. This inconsistency in approach tends to motivate award-creditors to be selective in their choice of forum in which to commence enforcement proceedings and ultimately execute an award. The issue of state immunity from execution has come to the fore in light of a number of recent attempts by award-creditors to attach their awards against the assets of a foreign state located in jurisdictions considered to be "pro-enforcement", such as France and Belgium. The success of these attempts in seizing foreign state assets has often strained diplomatic relations between states, prompting legislative intervention in these jurisdictions in order to clarify the rules on state immunity from execution, often in a way that safeguards foreign state property against attachment.

This chapter will briefly consider the reasons underlying the inconsistency in approaches to the application of the rules of state immunity from execution, as well

\footnotetext{
${ }^{1}$ Crawford (2019), p. 470; Jurisdictional Immunities of the State (Germany v. Italy: Greece intervening) Judgment [2012] ICJ Rep 99, para. 57.

${ }^{2}$ Fox and Webb (2013), p. 13 citing Al-Adsani v. UK (2002) 24 EHRR 11; Jones v. Minister of Interior of Saudi Arabia \& Ors [2006] UKHL 26; see also Jurisdictional Immunities of the State (Germany v. Italy: Greece intervening) Judgment [2012] ICJ Rep 99, para. 56; Report of the International Law Commission on the work of its Thirty-second session, UN GAOR, 35th sess, Supp No 10, UN Doc A/35/10 (5 May-25 July 1980) p. 147, para. 26.
} 
as the recent attempts by award-creditors to execute awards against foreign state property located in France and Belgium (Sect. 2). Section 3 outlines the legislative responses in France and Belgium to these proceedings and the introduction of procedural and substantive amendments to their respective laws on state immunity. The focus of this section is on the plea of state immunity from the execution of investment arbitration awards, from the perspective of the forum state. Section 4 of the chapter proposes possible alternatives for investors to enforcement and posits a way forward for investors seeking to navigate the landscape governing state immunity from execution.

\section{State Immunity from Jurisdiction and Execution}

State immunity acts as a procedural bar, ensuring that states and their representatives remain immune from the jurisdiction of foreign states' courts. ${ }^{3}$ The state may claim immunity at two stages of the proceedings: first, from the jurisdiction of the forum (which is known as "immunity from jurisdiction"), and secondly, from the execution of any resulting judgment (which is known as "immunity from execution"). The question of immunity from execution does not arise until jurisdiction has been established and the plaintiff (in this context, the investor) has received a judgment or arbitral award in its favour which it is seeking to enforce. ${ }^{4}$

\subsection{From Absolute to Restrictive}

At its inception, state immunity was absolute, meaning that a state would be immune from any foreign proceedings unless it provided its consent. Over time, this absolute approach was eroded in many jurisdictions to apply in a more restrictive fashion, only affording immunity to the state's sovereign acts. While this is true insofar as immunity from jurisdiction is concerned, the erosion of absolute immunity has been slower in the context of immunity from execution. National courts generally treat a state's immunity from execution as absolute, subject only to limited exceptions. ${ }^{5}$ While some consider this to be an "understandable" approach, owing to the fact that measures of constraint are far more intrusive than the exercise of declaratory

\footnotetext{
${ }^{3}$ Crawford (2019), p. 470; Fox and Webb (2013), p. 11.

${ }^{4}$ Draft Articles on Jurisdictional Immunities of States and Their Property, with commentaries, adopted by the International Law Commission in Report of the International Law Commission on the work of its forty-third session, UN GOAR, 49th sess, Supp No 10, UN Doc A/46/10 (29 April19 July 1991), p. 56.

${ }^{5}$ Van den Berg (1989), p. 13.
} 
jurisdiction by a foreign court, ${ }^{6}$ others have described the plea of immunity from execution as the "last bastion" of state immunity. ${ }^{7}$

\subsection{Lack of an International Regime}

There have been attempts to address the lack of consistency in the application of the rules of state immunity, with a small number of conventions dealing with state immunity. ${ }^{8}$ However, to date, there is no single international regime in force governing state immunity.

\subsubsection{United Nations Convention on Jurisdictional Immunities of States and Their Property}

Described as the "only sustained effort" to create a universal codification of international norms regarding state immunity, the United Nations Convention on Jurisdictional Immunities of States and Their Property (UNCSI) ${ }^{9}$ provides a "comprehensive code for the immunity of a State and its property". ${ }^{10}$ The relevant provision for the purposes of this chapter is Article 19, which deals with state immunity from post-judgment measures of constraint (such as attachment, arrest or execution). ${ }^{11}$ Article 19 provides for three exceptions to the general immunity afforded to foreign state property, which have been recognised by the International Court of Justice (ICJ) ${ }^{12}$ - where the state has expressly consented to the taking of such measures, where the state has allocated or earmarked property for the satisfaction of the claim which is the object of that proceeding, or where it has been

\footnotetext{
${ }^{6}$ Crawford (2019), pp. 488-489.

${ }^{7}$ Draft Articles on Jurisdictional Immunities of States and Their Property, with commentaries, adopted by the International Law Commission in Report of the International Law Commission on the work of its forty-third session, UN GOAR, 49th sess, Supp No 10, UN Doc A/46/10 (29 April19 July 1991), p. 56.

${ }^{8}$ For example, International Convention for the Unification of Certain Rules relating to the Immunity of State-owned Vessels, opened for signature 10 April 1926, (1937) 179 LNTS 199 (entered into force 8 January 1936), dealing with the immunity and liability of state ships in commercial use; European Convention on State Immunity, opened for signature 16 May 1972, (1972) 74 ETS 16 (entered into force 11 June 1976), a regional treaty in force between eight European states (Austria, Belgium, Cyprus, Germany, Luxembourg, Netherlands, Switzerland, United Kingdom), which adopts a restrictive approach to state immunity.

${ }^{9}$ United Nations Convention on Jurisdictional Immunities of States and Their Property, opened for signature 2 December 2004 (not yet in force).

${ }^{10}$ Fox and Webb (2013), p. 284.

${ }^{11}$ The equivalent provision for pre-judgment measures of constraint is Article 18 of the UNCSI.

${ }^{12}$ Jurisdictional Immunities of the State (Germany v. Italy: Greece intervening) Judgment [2012] ICJ Rep 99, para. 118.
} 
established that the property is in use or intended for use by the state for other than government non-commercial purposes. ${ }^{13}$ However, the UNCSI, while an influential instrument, has not yet entered into force. At the date of writing, the UNCSI has 22 ratifications, acceptances, approvals and accessions collectively, eight short of the required amount. ${ }^{14}$ This includes ratification by France (noting that it has only incorporated Articles 18, 19 and 21 into domestic law), but not Belgium.

\subsubsection{New York Convention and ICSID Convention}

The two key international conventions governing enforcement of arbitral awards are not forthcoming with any guidance as they only make scant provision for issues of state immunity. The Convention on the Recognition and Enforcement of Foreign Arbitral Awards (New York Convention) ${ }^{15}$ does not expressly mention state immunity, leaving this question to national laws. The Convention on the Settlement of Investment Disputes between States and Nationals of Other States (ICSID Convention) ${ }^{16}$ which governs the recognition and enforcement of investor-state dispute awards issued under the auspices of the delocalised ICSID Convention regime, does not contain any rules on state immunity. Article 54(3) provides that the execution of ICSID awards is governed by local laws, and Article 55 (an "interpretation" of Article 54) ${ }^{17}$ states that the ICSID Convention does not seek to modify the laws of contracting states with respect to immunity from execution. Together, the two provisions have created enormous difficulties for investors attempting to enforce awards, earning their title as the "Achilles' heel" of the ICSID regime. ${ }^{18}$

\subsubsection{Divergence in National Approaches}

As a result of the comparative void left by international conventions, questions of state immunity are largely left to be resolved by national laws and interpretation by national courts. ${ }^{19}$ However, the divergence in the application of the doctrine of state immunity is "conspicuous not only as between various States but also in the internal

\footnotetext{
${ }^{13}$ The so-called "commercial property" exception was considered by the High Court of Australia in Firebird Global Master Fund II Ltd v. Republic of Nauru (2015) 258 CLR 31.

${ }^{14}$ Article 30 of the UNCSI.

${ }^{15}$ Convention on the Recognition and Enforcement of Foreign Arbitral Awards, opened for signature 10 June 1958 (1959) 330 UNTS 38 (entered into force 7 June 1959).

${ }^{16}$ Convention on the Settlement of Investment Disputes between States and National of Other States, opened for signature 18 March 1965 (1966) 575 UNTS 159 (entered into force 14 October 1966).

${ }^{17}$ Schreuer et al. (2009), p. 1142.

${ }^{18}$ Schreuer et al. (2009), p. 1144.

${ }^{19}$ Juratowitch (2016), p. 200.
} 
jurisprudence of States" 20 and as between civil and common law countries. Codification of state immunity started with the adoption of the Foreign Sovereign Immunities Act in the United States ${ }^{21}$ followed by the introduction of similar legislation in the United Kingdom, Australia and other common law jurisdictions. ${ }^{22}$ Although these regimes are broadly similar, adopting the restrictive doctrine of immunity, they have subtle and important differences. The "unusual situation" resulting from this trend is that many common law regimes now have legislation in force dealing with state immunity, whereas in civil law countries, the question of state immunity has traditionally been left to the judiciary. ${ }^{23}$

The approaches adopted by different states to the application of the doctrine of state immunity will not be explored in this chapter. It suffices to note for the purposes of this contribution one practical consequence resulting from this divergence in approach - a sort of "forum shopping" by award-holders in determining the optimal forum in which to seek the enforcement and, ultimately, the execution of an award. ${ }^{24}$ Seeking the enforcement and execution of an arbitral award through the domestic courts of a foreign state in which assets belonging to the debtor state are located tends not to be a straightforward matter. For investors who have obtained awards under the ICSID regime, the process is slightly more streamlined, as all parties to the ICSID Convention have an obligation to recognise an award as binding and enforce the pecuniary obligations arising under such an award as if it were a final judgment of a domestic court. ${ }^{25}$ Thus, such investors are able to obtain recognition and enforcement of ICSID awards before the courts of contracting states to the ICSID Convention (akin to a process of "exequatur"), and the courts do not have the ability to decline recognition and enforcement of the award for reasons of, for example, public policy. As for those investors who have obtained an award under the auspices of any other arbitral rules, it is necessary to first seek recognition and enforcement of

\footnotetext{
${ }^{20}$ Survey of International Law in Relation to the Work of Codification of the International Law Commission: Preparatory work within the purview of article 18, paragraph 1, of the International Law Commission-Memorandum submitted by the Secretary-General (1949), UN Doc A/CN.4/1/ Rev.1, para. 52.

${ }^{21}$ Foreign Sovereign Immunities Act, 28 USC 97 §1602-11 (1976).

${ }^{22}$ State Immunity Act 1978 (UK), c 33; Foreign States Immunities Act 1985 (Cth); State Immunity Act, RSC 1985, c. S-18 (Canada); State Immunity Act (Singapore, c 313, 1979 rev ed); Foreign States Immunities Act 1981 (South Africa).

${ }^{23}$ Bjorklund (2009), pp. 309-310.

${ }^{24}$ Matute C (2016), "Forum Shopping in the Execution of ICSID Awards: Is it Time to Revive the UN Convention on State Immunity?" Kluwer Arbitration Blog, 24 June 2016. While there are some evident difficulties in terminology by the seemingly inconsistent and interchangeable use of the terms "enforcement" and "execution", it is the author's view that the two terms should be understood as referring to different concepts. At a high level, "recognition and enforcement" means domesticating the award (akin to exequatur in civil law jurisdictions), whereas "execution" refers to the actual attachment or seizure of foreign state property. See Juratowitch (2016), pp. 216-219; see discussion in Eiser Infrastructure Ltd v. Spain [2020] FCA 157, [89]-[176] per Stewart J.

${ }^{25}$ Article 54(1) of the ICSID Convention.
} 
the award by the national courts of the jurisdiction in which the investor is seeking to execute its award. While such recognition is facilitated by the widely ratified New York Convention, ${ }^{26}$ it is not automatic and there are clear grounds on which the debtor state might seek to have the recognition and enforcement of the award refused. ${ }^{27}$ Recognition and enforcement will not, however, be the final step for the investor, who must also seek execution of the award by identifying non-immune assets of the debtor state which can be attached or seized in satisfaction of the debt arising under the award.

\subsection{Enforcement}

In the context of investor-state dispute settlement, the incentive of protecting reputation encourages host states subject to investment treaty claims to comply voluntarily with arbitral awards. ${ }^{28}$ Indeed, it should be noted that for the most part, states are compliant with such awards. Notwithstanding this incentive, a handful of states have refused to comply with awards, prompting a spate of enforcement proceedings by award-creditors. ${ }^{29}$ Examples of two of these proceedings commenced by NML Capital Ltd (NML), an affiliate of a New York based hedge fund of a type sometimes described as a "vulture fund", 30 and the three controlling shareholders of Yukos Oil Company (Yukos) respectively, seeking the attachment of Russian assets located in France and Belgium, are introduced below.

\subsubsection{NML and Republic of Argentina}

After Argentina defaulted on its sovereign debt in 2001, affiliates of NML purchased, at a little over half their face value, bonds issued by the Government of Argentina. On 11 May 2006, NML, as beneficial owner, obtained a summary judgment on the bonds in the order of US\$284 million from a Federal Court in

\footnotetext{
${ }^{26}$ Article III of the New York Convention.

${ }^{27}$ Article V of the New York Convention.

${ }^{28}$ Bonnitcha et al. (2017), p. 78.

${ }^{29}$ For example, the enforcement proceedings pursued by Mr Franz Sedelmayer and Société NOGA against the Russian Federation. Mr Sedelmayer successfully executed his award against Russian property located in Germany and Sweden (Oberlandesgericht Frankfurt am Main, 26 W 101/02, 26 September 2002; Oberlandesgericht Köln, 22 U 98/07, 18 March 2008; Russian Federation v. Sedelmayer, Sweden Sup Ct, No Ö 170-10, 1 July 2011). In contrast, the enforcement proceedings commenced by Société Noga in France, the US and Switzerland, were not as successful. 30"Vulture funds feed on the debts of sovereign states that are in acute financial difficulty by purchasing sovereign debt at a discount to face value and then seeking to enforce it": NML Capital Limited (Appellant) v. Argentina (Respondent) [2011] UKSC 31, para. 1, per Lord Phillips.
} 
New York. ${ }^{31}$ Relying on an express waiver of immunity from enforcement contained in the governing bond agreement, NML commenced enforcement proceedings in Belgium and France (among other jurisdictions) in an attempt to garnish Argentina's assets. NML was unsuccessful in attaching Argentinian diplomatic goods located in Belgium, as a Belgian Court held that the general waiver of immunity in question did not include diplomatic assets unless it specifically mentioned those goods. ${ }^{32}$ The French courts arrived at a similar conclusion, lifting a provisional attachment of the bank accounts of the Argentine Embassy and Permanent Delegation of Argentina to the United Nations Educational, Scientific and Cultural Organisation (UNESCO) on the basis that the waiver was not express and specific. ${ }^{33}$ This line of reasoning is explored in greater detail below. ${ }^{34}$

\subsubsection{Yukos and the Russian Federation}

Perhaps the best-known example of enforcement proceedings is the attempt by the three controlling shareholders of Yukos to execute their respective arbitral awards, totalling over US\$50 billion, ${ }^{35}$ against assets of the Russian Federation located in the United States, the United Kingdom, France, Belgium, Germany, and India. All enforcement proceedings had been either terminated or suspended, following the decision of The Hague District Court to set aside the largest ever award issued by the Permanent Court of Arbitration on jurisdictional grounds. ${ }^{36}$ However, the District Court's decision has recently been reversed by The Hague Court of Appeal, ${ }^{37}$ and the arbitral awards have been reinstated. The Russian Federation has appealed this decision. It will be interesting to observe the approach of the award creditors to their enforcement proceedings. This section discusses the efforts of the shareholders to execute their awards against Russian assets located in France and Belgium to date.

\footnotetext{
${ }^{31}$ NML Capital Ltd v. Argentina, No 05 Civ 2434 (SDNY, 2006).

${ }^{32}$ NML Capital Ltd v. Republique d'Argentine, Cour de cassation de Belgique, 22 November 2012, C.11.0688.F, p. 18.

${ }^{33}$ Cour de cassation, civile, Chambre civile 1, 28 September 2011, 09-72.057.

${ }^{34}$ See Sects. 3.1.1 and 3.1.2.

${ }^{35}$ Hulley Enterprises Limited, Yukos Universal Limited, and Veteran Petroleum Limited. Hulley Enterprises Ltd (Cyprus) v. Russian Federation, PCA Case No. AA 226, Award, 18 July 2014; Yukos Universal Ltd (Isle of Man) v. Russian Federation, PCA Case No. AA 227, Award, 18 July 2014; Veteran Petroleum Ltd (Cyprus) v. Russian Federation, PCA Case No. AA 228, Award, 18 July 2014.

${ }^{36}$ The Court found that the Permanent Court of Arbitration had no jurisdiction to hear the case, as the Russian Federation had not ratified the Energy Charter Treaty (under which the case was brought). The former Yukos shareholders appealed this decision in The Hague Court of Appeal. In September 2019, the Court conducted oral hearings in relation to the appeal.

${ }^{37}$ The Hague Court of Appeal upheld the arbitral tribunal's jurisdiction based on an "alternative interpretation" of the Energy Charter Treaty's provisional application clause submitted by the investors on appeal.
} 
At the time, France enjoyed a reputation as a pro-enforcement jurisdiction, with French courts promoting recognition and allowing the enforcement of arbitral awards that had been set aside in their country of origin. ${ }^{38}$ The shareholders enjoyed initial success, with the granting of an exequatur by the Tribunal de grande instance de Paris in December 2014. Following this decision however, a number of attachments were made but subsequently lifted. For example, the Tribunal de grande instance de Paris upheld Russia's immunity from execution in respect of land near the Eiffel Tower on which Russia was constructing a cathedral. ${ }^{39}$ The awardcreditors were similarly met with mixed success in Belgium. In June 2015, Belgian courts froze the bank accounts of Russia's EU, Belgian and North Atlantic Treaty Organization (NATO) missions and ordered a number of Russian and international organisations to present any information regarding Russian owned assets. ${ }^{40}$ Russia declared this to be an "openly unfriendly act" and threatened retaliatory measures, ${ }^{41}$ and Belgium unfroze the assets after only a few days. ${ }^{42}$

Even if the Yukos shareholders were to revive their enforcement proceedings in France and Belgium following the recent decision of The Hague Court of Appeal, it is likely that they would face challenges going forward. The enforcement landscape in France and Belgium has undergone legislative change, introducing procedural and substantive amendments which may have the effect of deterring, or at least rendering more difficult, enforcement proceedings going forward.

\section{Legislative Amendments in France and Belgium}

In the wake of the Yukos enforcement proceedings, new legislation was introduced in France and Belgium codifying national law on state immunity from the execution of judgments and arbitral awards in December 2016 and September 2015 respectively. The relevant legislation in France was introduced as a rider to the "Loi Sapin $I I^{\prime}$ ' on transparency, anti-corruption and the modernisation of the economic life,

\footnotetext{
${ }^{38}$ For example, Cour de cassation, Société Hilmarton Ltd v. Société Omnium de traitement et de valorisation (OTV), 92-15.137, 23 March 1994; Cour de cassation, Société PT Putrabali Adyamulia v. Société Rena Holding et Société Moguntia Est Epices, 05-18.053, 29 June 2007.

${ }^{39}$ Hulley Enterprises v. Russia and Société Bouygues Batiment Ile de France, Tribunal de grande instance de Paris, No RG 15/00323, 28 April 2016.

${ }^{40}$ Dilevka S, Attachment of Russia owned assets in Belgium (22 June 2015) Russian Arbitration Association http://arbitrations.ru/en/press-centr/news/attachment-of-russian-owned-assets-in-bel gium/.

${ }^{41}$ The Economist, The Yukos Affair: A ghost bites back (27 June 2015) http://www.economist. com/news/business/21656191-shareholders-what-was-once-russias-biggest-oil-company-scent-vic tory-ghost-bites-back.

${ }^{42}$ Gololobov (2015), p. 9 citing Brussels Says Blocked Russian Accounts Being Unfrozen (21 June 2015) Reuters (UK) http://uk.reuters.com/article/uk-russia-yukos-brusselsidUKKBNOP10DW20150621.
} 
introduced by the Minister of Finance, Michel Sapin. ${ }^{43}$ The law introduced a raft of reforms targeted towards French anti-corruption laws and also contained some important changes to the treatment of measures of constraint available over foreign state assets. The Belgian law, Article 1412quinquies of the Belgian Code Judiciaire, introduced a general principle that assets located in Belgium belonging to a foreign state are immune from execution. Both laws were accorded urgent treatment, ${ }^{44}$ were the subject of highly contested debates, and were motivated by the desire to protect diplomatic relations by avoiding diplomatic incidents at all costs. ${ }^{45}$

The French and Belgian laws have a similar structure, conferring a general state immunity, ${ }^{46}$ subject to three exceptions: waiver, allocated or earmarked assets, and commercial property. ${ }^{47}$ It is worth noting two substantive and procedural requirements introduced by each law-an "express and specific" waiver (Sect. 3.1) and preliminary judicial authorisation (Sect. 3.2).

\subsection{First Requirement: Express and Specific Waiver}

First, the laws introduce a requirement that any waiver be "express and specific". 48 This applies in respect of all foreign state property in Belgium, ${ }^{49}$ and in respect of diplomatic property in France (an "express" waiver is sufficient for other state property in France). The requirement had been introduced in the jurisprudence of the French and Belgian courts, which is explored below.

\subsubsection{Development of Case Law in France}

In France, the task of developing and applying the relevant rules of state immunity was left to the courts, owing to the lack of comprehensive statutory rules governing

\footnotetext{
${ }^{43}$ Loi no 2016-1691 du 9 décembre 2016 relative à la transparence, à la lutte contre la corruption et à la modernisation de la vie économique.

${ }^{44}$ The Belgian law entered into force on 13 September 2015, 73 days after its proposal.

${ }^{45}$ Projet de loi-Étude d'impact (France) (30 March 2016), p. 91; Proposition de loi-Rapport (Belgium) (23 July 2015) Doc 54-1241/005, p. 3.

${ }^{46}$ Article 1412quinquies $\$ 1$ er of the Code Judiciaire (Belgium); Article 59 L. 111-1-1 of the Loi Sapin II (France).

${ }^{47}$ Article 1412quinquies $\$ 2,1^{\circ}-3^{\circ}$ of the Code Judiciaire (Belgium); Article L111-1-2, $1^{\circ}-3^{\circ}$ and Article L111-1-3 of the Loi Sapin II (France).

${ }^{48}$ The French law requires that any waiver be "expresse et spéciale" (Article L. 111-1-3); the Belgian law requires that a foreign state has "expressément et spécifiquement" consented (Article 1412 quinquies $\S 2,1^{\circ}$ ).

${ }^{49}$ Note, however, that the Belgian Cour constitutionnelle has since annulled the requirement of the word "specifically" in Article 1412quinquies insofar as it applies to non-diplomatic assets (see Sect. 3.1 .2 below).
} 
the matter (prior to Loi Sapin II, the legislature had only introduced two articles dealing with state immunity). ${ }^{50}$ The French courts have not approached the question of immunity from execution in a consistent manner.

At one end of the spectrum is the decision of the highest court in the French judiciary, the Cour de cassation, in Creighton v. Qatar. ${ }^{51}$ The Cour de cassation held that an arbitration clause containing a submission to the Rules of the International Chamber of Commerce constituted a valid waiver of immunity from jurisdiction and execution. The decision represented a departure from prior reasoning of the judiciary-that immunity from jurisdiction and execution were "not interconnected" $" 52$ and the waiver of one did not remove the right to invoke the other. ${ }^{53}$ The decision has been criticised as taking a "very far-reaching step" in the development of French law. ${ }^{54}$

Following this decision, the French courts developed a line of reasoning with respect to state immunity from execution against diplomatic property. In Ambassade de la fédération de Russie en France v. Société NOGA, ${ }^{55}$ the Cour d'appel de Paris refused execution against diplomatic assets. The foreign state, the Russian Federation, had signed an arbitration clause and an explicitly drafted waiver of "tout droit d'immunite." 56 The Swiss company sought to execute its award against, inter alia, certain bank accounts located in France in the name of the Russian embassy, the Russian commercial delegation, and its permanent delegation to UNESCO. ${ }^{57}$ The Cour d'appel de Paris refused execution as the waiver was too general. It held that diplomatic immunity was governed by the distinct legal regime of the 1961 Vienna Convention on Diplomatic Relations (VCDR), ${ }^{58}$ which cannot be presumed to come within the general waiver of immunity from execution. ${ }^{59}$ This approach was later

\footnotetext{
${ }^{50}$ Article L. $153-1$ of the French Monetary and Financial Code; Article L. 111 of the French Code of Civil Enforcement Procedures.

${ }^{51}$ Cour de cassation, Chambre civile 1, 6 July 2000, 98-19.068.

${ }^{52}$ Socifros v. USSR, Cour d'appel d'Aix, 23 November 1938 reported in (1938) 9 Ann Dig 236, 237.

${ }^{53}$ République Islamique d'Iran et consorts v. Sociétés Eurodif et Sofidif, Cour d'appel de Paris, 21 April 1982 reported in (1982) 65 International Law reports 93, 97; Socialist Federal Republic of Yugoslavia v. Société Europeenne d'Etudes et d'Entreprises, Tribunal de grande instance de Paris, 6 July 1970 reported in (1971) Journal de Droit International 98.

${ }^{54}$ Gaillard (2002), p. 250.

${ }^{55}$ Ambassade de la fédération de Russie en France v. Société NOGA, Cour d'appel de Paris, No 2000/14157, 10 August 2000, reported in (2001) Rev Arb 114.

${ }^{56}$ This phrase translates as "any right of immunity".

${ }^{57}$ Miles (2009), pp. 67-68; Blane (2009), p. 471; Caroit et al. (2015), p. 237.

${ }^{58}$ Vienna Convention on Diplomatic Relations, opened for signature 18 April 1961, (1962) 500 UNTS 95 (entered into force 24 April 1964).

${ }^{59}$ Gaillard (2002), p. 251.
} 
affirmed, in a case involving an even more broadly drafted waiver. ${ }^{60}$ One can be sympathetic to the justification for the more stringent standard by according recognition of the special status of diplomatic activities as being at the heart of sovereign activity.

The Cour de cassation confirmed in the first of four cases relating to the immunity of Argentina from execution of awards in favour of NML that, pursuant to customary international law, diplomatic missions of foreign states enjoy an autonomous immunity which can only be waived in an express and specific manner. ${ }^{61}$ In three cases decided on the same day in 2013, the Cour de cassation extended this reasoning by finding that, pursuant to customary international law as reflected in the UNCSI, a waiver in respect of property or categories of property used or intended to be used for governmental purposes must be express and specific. The Cour de cassation's reading of the UNCSI has been criticised. ${ }^{62}$

In an unexpected turn, the Cour de cassation "loosened up" this requirement in République $d u$ Congo v. Commisimpex (Commisimpex) $;{ }^{63}$ a case concerning a dispute between the Republic of the Congo (Congo) and a Congolese company (Commisimpex) regarding the performance of a contract to construct a women's hospital in the Qatari capital, Doha. In 2011, Commisimpex sought to enforce an award issued in its favour. Commisimpex was initially successful in obtaining attachment of Congolese assets in Paris, including numerous accounts held in the name of the Congo's diplomatic mission and its UNESCO delegation. ${ }^{64}$ Commisimpex relied on a general waiver in a letter of undertaking from the Congo, waiving its right to "invoke, in the context of the settlement of a dispute [...] any immunity of jurisdiction as well as any immunity of execution" 65 The

\footnotetext{
${ }^{60}$ République du Cameroun v. Winslow Bank \& Trust, Cour d'appel de Paris, 26 September 2001, reported in (2001) Dalloz IR 3017; the waiver included all immunities that the Republic "would be entitled [...] to invoke for itself or for its assets [...] or any other immunity it may have," specifying that "the borrower consents [...] to [...] the execution against any assets (no matter what they are used for or designated to be used for)."

${ }^{61}$ Cour de cassation, civile, Chambre civile 1, 28 September 2011, 09-72.057.

${ }^{62}$ Franc-Menget (2013), p. 997; Cour de cassation, civile, Chambre civile 1, 13 May 2015, 13-17.751.

${ }^{63}$ Langlois and Ioannou (2016).

${ }^{64}$ Franc-Menget (2015), p. 507; Franc-Menget Land Archer P, "French Supreme Court decision in Commisimpex dispute heralds significant change in approach to sovereign immunity" on Herbert Smith Freehills Public International Law Notes (4 June 2015) http://hsfnotes.com/ publicinternationallaw/2015/06/04/french-supreme-court-decision-in-commisimpex-dispute-her alds-significant-change-in-approach-to-sovereign-immunity/.

${ }^{65}$ The terms of the general waiver in French were as follows: "à invoquer dans le cadre du règlement d'un litige [...] toute immunité de juridiction ainsi que toute immunité d'exécution" (Cour de cassation, civile, Chambre civile 1, 13 May 2015, 13-17.751); Franc-Menget L and Archer P, "French Supreme Court decision in Commisimpex dispute heralds significant change in approach to sovereign immunity" on Herbert Smith Freehills Public International Law Notes (4 June 2015) http://hsfnotes.com/publicinternationallaw/2015/06/04/french-supreme-court-deci sion-in-commisimpex-dispute-heralds-significant-change-in-approach-to-sovereign-immunity/.
} 
discharge of the assets was ordered at first instance and affirmed on appeal. The Cour d'appel de Versailles adopted the words of the Cour de cassation in NML Capital Ltd v. Argentina, ${ }^{66}$ noting that diplomatic missions of foreign states benefit from an absolute immunity from execution which can only be waived in an "expresse et spéciale" manner. ${ }^{67}$ The Congo's general waiver did not meet this requirement.

On appeal to the Cour de cassation, Commisimpex was successful. Commisimpex's primary argument was that the Cour d'appel had misunderstood the nature of customary international law by finding that diplomatic assets enjoy an absolute immunity, the waiver of which must be express and specific. Rather, Commisimpex submitted that no such general consensus existed, as required by Article 38(1)(b) of the Statute of the International Court of Justice. The Cour de cassation accepted this argument. It held, reversing its 2013 decision and abandoning the "specific" requirement, that the rules of customary international law " $n$ 'exigent pas une renonciation autre qu'expresse à cette immunité." 68

By introducing the Loi Sapin II, the French Government substantially reinstated the position that existed prior to Commisimpex. That is, affording an almost absolute immunity to diplomatic assets by requiring an express and property-specific waiver. Following the introduction of this law, the Congo challenged the decision of the Cour de cassation, on the grounds that the new rules expressly provide that a creditor is prohibited from attaching diplomatic assets in the absence of an express and specific waiver. The Cour de cassation departed from its previous jurisprudence, abandoning what it described as an "isolated doctrine", 69 and held that an express waiver was not sufficient without specificity for the purpose of seizing diplomatic assets. ${ }^{70}$ In doing so, the Cour de cassation was cautious to justify its position by reference to older jurisprudence (most likely referring to the NML decision discussed above) and to the need for consistency and legal certainty, as opposed to the new Loi Sapin II, which it acknowledged could not apply retroactively to the dispute. $^{71}$ As such, the Cour de cassation confirmed that the seizure of the Congolese bank accounts should be lifted.

\footnotetext{
${ }^{66}$ Cour de cassation, civile, Chambre civile 1, 28 March 2013, 10-25.938; Cour de cassation, civile, Chambre civile 1, 28 March 2018, 11-10.450; Cour de cassation, civile, Chambre civile 1, 28 March 2013, 11-13.323.

${ }^{67}$ Cour d'appel de Versailles, 15 November 2012, 11-09.073; see also, Franc-Menget (2015), n 8.

${ }^{68}$ This phrase translates as "do not require a waiver from this immunity [that is anything] other than express." Cour de cassation, civile, Chambre civile 1, 13 May 2015, 13-17.751. The Cour de cassation ultimately referred the case to the Cour d'appel to rule on the merits of the legality of the seizure.

${ }^{69}$ The language used by the Cour de cassation was as follows: "la doctrine isolée résultant de l'arrêt du 13 mai 2015" (Cour de cassation, 1er chambre civile, 10 January 2018, 16-22.494).

${ }^{70}$ Cour de cassation, 1ère chambre civile, 10 January 2018, 16-22.494.

${ }^{71}$ See discussion in Malet-Deraedt (2018), pp. 337-338.
} 


\subsubsection{Development of Case Law in Belgium}

The justification underpinning the application of the requirement that a state consent "expressément et spécifiquement" to the attachment of all of its assets (not just diplomatic property) located in Belgium is less clear. The Chambre des représentants introduced this requirement into parliament, explaining that it removed all ambiguity around the word "express". ${ }^{72}$ By way of authority, it cited a judgment of the Belgian Cour de cassation of 22 November 2012, concerning the dispute between NML and the Republic of Argentina referred to above. ${ }^{73}$ NML commenced enforcement proceedings in Belgium and sought to attach Argentinian diplomatic goods. The court noted the argument that neither the VCDR, nor any other convention in force, nor customary international law provides for a "specific" waiver for the bank accounts of diplomatic missions. ${ }^{74}$ However, the court held, disagreeing with the lower court's decision, that a general waiver of immunity did not include diplomatic assets unless it specifically mentioned those goods. ${ }^{75}$

Article 1412quinquies codifies the reasoning of the Belgian Cour de cassation, and extends the express and specific waiver requirement to all property. The Belgian Cour constitutionnelle has, however, since annulled the requirement of the word "specifically" in Article 1412quinquies insofar as it applies to non-diplomatic assets. ${ }^{76}$ In light of the difficulty of meeting the requirements introduced by Article 1412quinquies, Yukos and NML commenced proceedings to set aside the new law on the ground that it was unconstitutional. ${ }^{77}$ The Cour constitutionnelle noted that the reference to the word "specifically" was problematic as it was not contained in the UNCSI, nor had it been referred to by the ICJ in this context. On this basis, the word "specifically" had to be annulled in respect of property that was not used for diplomatic purposes. The Cour constitutionnelle confirmed the validity of the balance of Article 1412quinquies.

\subsection{Second Requirement: Preliminary Judicial Authorisation}

The second aspect of the laws worth noting is the introduction of a requirement that a creditor obtain prior authorisation from a judge ( judge des saisies) before taking any

\footnotetext{
${ }^{72}$ Proposition de loi-Amendements (Belgium) (22 July 2015) Doc 54-1241/004.

${ }^{73}$ See Sect. 2.3.1; NML Capital Ltd v. Republique d'Argentine, Cour de cassation de Belgique, 22 November 2012, C.11.0688.F.

${ }^{74}$ NML Capital Ltd v. Republique d'Argentine, Cour de cassation de Belgique, 22 November 2012, C.11.0688.F, p. 9.

${ }^{75}$ NML Capital Ltd v. Republique d'Argentine, Cour de cassation de Belgique, 22 November 2012, C.11.0688.F, p. 18.

${ }^{76}$ Belgian Constitutional Court, Rolnummers 6372 en 6373, Arrest nr. 48/2017, 27 April 2017, p 30 [B.21].

${ }^{77}$ Belgian Constitutional Court, Rolnummers 6372 en 6373, Arrest nr. 48/2017, 27 April 2017.
} 
measures of constraint. This obliges a creditor with an enforceable title (exequatur) to request authorisation from the attachment judge in France or Belgium by demonstrating in ex parte proceedings that the property is suitable for seizure. This requirement already existed for provisional measures in France.

The motivation behind the introduction of this requirement was primarily to offer greater judicial security to foreign states, ${ }^{78}$ and to ensure that creditors cannot seize foreign state property, including immune property, before a plea of state immunity from execution is considered. This also ensures that the interests of the foreign state, including any immunity claims it may make, are adequately protected. The Belgian drafters opined that seizures of property could be done in such a short period of time and sometimes without intervention by a judge that one could not presume a perfect knowledge of international law on the part of those who were participating in the seizure. ${ }^{79}$ The French drafters were concerned with certain creditors who, knowing that their request is not entirely legitimate, apply for execution to bailiffs who do not necessarily know the subtleties of international law. Although these creditors are generally unsuccessful, in the interim period, the creditors are in a position of power to engage in discussions with the foreign state. ${ }^{80}$ The intention was for the preliminary judicial authorisation procedure to act as a "filter" against applications by creditors, limiting their "abusive" seizures. ${ }^{81}$

\subsubsection{Compatibility with the European Convention on Human Rights}

The requirement for preliminary judicial authorisation has been criticised as imposing an unduly onerous burden on award-creditors to prove that targeted property is non-governmental, particularly as states are under no obligation to assist with collating evidence. Its compatibility with the right to court access secured by Article 6 of the European Convention on Human Rights (ECHR) ${ }^{82}$ has also been called into question. Critics of the law argue that it may preclude meaningful court access, as the execution of an award is considered as "forming an integral part of the 'process' at the heart of article $6 " .83$

However, in their challenge in the Cour constitutionnelle, ${ }^{84}$ Yukos and NML unsuccessfully argued that the requirements were disproportionate and violated the ECHR since they precluded a creditor from effectively enforcing a judgment or an

\footnotetext{
${ }^{78}$ Proposition de loi-Rapport (Belgium) (23 July 2015) Doc 54-1241/005, p. 7.

${ }^{79}$ Proposition de loi-Rapport (Belgium) (23 July 2015) Doc 54-1241/005, p. 9.

${ }^{80}$ Compte rendu intégral-Séance publique du jeudi 7 juillet 2016 (France) Sénat No 76 S (8 July 2016), 12540 (M. Sapin).

${ }^{81}$ Projet de loi-Rapport No 3785 (France) (26 May 2016), p. 278.

${ }^{82}$ European Convention on Human Rights, as amended by Protocols Nos. 11 and 14, opened for signature 4 November 1950, [1950] COETS 1 (entered into force 3 September 1953).

${ }^{83}$ Hornsby v. Greece (1997) 24 EHRR 250.

${ }^{84}$ Discussed above in Sect. 3.1.2.
} 
award rendered against the foreign state. ${ }^{85}$ A similar claim brought against France was found by the European Court of Human Rights to be inadmissible for failure to exhaust domestic remedies. ${ }^{86}$ To date, the European Court of Human Rights has held that the grant of state immunity in accordance with international practice does not infringe Article $6 .{ }^{87}$ It has held that "the grant of immunity to a State in civil proceedings pursues the legitimate aim of complying with international law to promote comity and good relations between States through the respect of another State's sovereignty". 88

\subsubsection{Executive Authorisation}

The requirement for some form of pre-attachment authorisation is not unique to France and Belgium. Indeed, some states require executive authorisation for enforcement measures against the property of foreign states. ${ }^{89}$ Unlike the regime of pre-attachment judicial review in place in France and Belgium, the power to prevent the attachment of assets located in the Netherlands, or render an attachment null and void, is vested in the Dutch Ministry of Justice. Bailiffs in the Netherlands who assist with the attachment proceedings are statutorily obliged to report to the Dutch Ministry of Justice once a request for attachment of a foreign state's assets has been received which may be in violation of the state's international obligations. ${ }^{90}$ Should the executive branch exercise its power to prevent, or render null and void, an attachment of assets, the award-creditor must demonstrate in court proceedings that the relevant assets are not covered by sovereign immunity, which shall be presumed by Dutch courts. ${ }^{91}$ This approach has been criticised as it has been seen to politicise the decision to grant or deny an attachment of assets. ${ }^{92}$ A similar requirement for executive authorisation has been successfully challenged as being contrary to the

\footnotetext{
${ }^{85}$ Belgian Constitutional Court, Rolnummers 6372 en 6373, Arrest nr. 48/2017, 27 April 2017. ${ }^{86}$ NML Capital Ltd v. France, ECHR, Decision, App no 23242/12, 13 January 2015.

${ }^{87}$ Crawford (2019), p. 490; Kalogeropoulou and others v. Greece and Germany (2002) 129 ILR 537; Al-Adsani v. UK (2001) 123 ILR 24.

${ }^{88}$ Al-Adsani v. UK (2001) 123 ILR 24 [54].

${ }^{89}$ E.g. Article 18 of the Execution Act (Official Gazette of the Republic of Croatia, No. 57/96) provides that "[a]n act of execution or an act of securing canot be issued against the property of a foreign State without previous consent of the Ministry of Justice of the Republic of Croatia, except when a foreign State agrees on execution or securing."

${ }^{90}$ Barten and Krestin (2017).

${ }^{91}$ In 2016, the Dutch Supreme Court confirmed a general presumption of immunity from enforcement of judgments and arbitral awards against a foreign state's assets: see Morning Star International Corporation v. Republic of Gabon, ECLI: NL: HR: 2016: 2236, 30 September 2016.

${ }^{92}$ Reinisch (2006), p. 813.
} 
constitutional right of access to court enshrined in Article 24 of the Italian Constitution. $^{93}$

\subsection{Legislative Developments in Russia}

It would be remiss not to mention in this context the legislative developments that have taken place in the Russian Federation, following the numerous attempts of execution against its property. On 1 January 2016, a new law came into force in Russia "On the jurisdictional immunities of foreign States and property of a foreign state in the Russian Federation". 94 The law implements a version of restrictive immunity from execution, despite the nation's traditional adherence to absolute immunity, subject to reciprocity. The law grants Russian courts the power to lower the level of protection afforded to foreign states based on the degree of immunity afforded to the Russian Federation in that foreign state. ${ }^{95}$ The consistency between legislating in respect of state immunity on the basis of reciprocity and the forum state's obligation to afford immunity has been questioned. ${ }^{96}$ Putting questions of validity to one side, the approach of the Russian Federation may work to reduce the protection enjoyed by foreign states in future enforcement proceedings.

\section{Alternatives to Enforcement and Looking Forward}

While the phenomenon of non-compliance with arbitral awards has the potential to undermine the utility of investor-state dispute settlement entirely, leaving awardcreditors with a pyrrhic victory, the majority of debtor states do in fact comply with arbitral awards. ${ }^{97}$ The practice of a few states should not be seen as representing the majority. Indeed, states tend to prefer to abide by decisions of tribunals to avoid the consequences of non-compliance for a state's reputation with private and public

\footnotetext{
${ }^{93}$ Decreto Legge, Article 1, 30 August 1925, No. 1621, becoming law by Statute of 15 July 1926, No. 1263. The law provided that "there shall be no attachment, seizure or, in general, measures of execution against the movable or immovable property, vessels, funds, securities and any other assets belonging to a foreign State, without the authorization of the Minister of Justice." See Reinisch (2006), p. 814.

${ }^{94}$ Federal Law No 297-FZ, "On the jurisdictional immunities of foreign States and property of a foreign state in the Russian Federation", entry into force 1 January 2016. In the joint "Declaration of the Russian Federation and the People's Republic of China on the Promotion of International Law" (25 June 2016), the Russian Federation confirmed the applicability of the doctrine of state immunity.

${ }^{95}$ Article 4 of the Federal Law No 297-FZ.

${ }^{96}$ Fox and Webb (2013), p. 14.

${ }^{97}$ Kehoe (2009), p. 265; Saunders and Salomon (2007), p. 469.
} 
sources of international finance. ${ }^{98}$ One cannot deny, however, the potential for non-compliance. This section considers the alternatives to execution available to award-creditors and posits a way forward for investors seeking to navigate the landscape governing state immunity from execution.

\subsection{Alternatives to Enforcement}

When faced with a state claiming immunity from execution, two broad alternatives to enforcement are available to an award-creditor. ${ }^{99}$ First, the parties may reach a settlement agreement. While prompt payment may follow, this would usually be at the cost of a significantly lower amount, particularly given the leverage a claim of immunity provides a state in settlement discussions. In addition, states have a number of concerns when faced with the prospects of reaching a settlement agreement in circumstances necessarily lacking transparency (for example, through a mediated settlement agreement). Such concerns were canvassed by a 2017 Survey on Obstacles to Settlement of Investor-State Disputes conducted by the National University of Singapore's Centre for International Law. Ranking among the highest obstacles preventing states from settling a dispute included the desire to avoid or defer responsibility to an independent decision-maker and the fear of future prosecution for corruption. 100

The second option is for the award-creditor to lobby its home state to exert political pressure on the debtor state, similar to a traditional diplomatic protection claim. ${ }^{101}$ A claim of diplomatic protection is available as a state will still be under an obligation to abide by an award even though it has submitted a plea of immunity from execution, which operates as a procedural bar. Such a claim is contemplated by Article 27 of the ICSID Convention, which provides for the right of diplomatic protection in case of non-compliance by a respondent state with an award. In exercising diplomatic protection, a home state might also invoke the compulsory jurisdiction of the ICJ under Article 64 of the ICSID Convention, which provides for the referral to the ICJ of any dispute concerning the interpretation or application of the ICSID Convention. It has been noted that providing for diplomatic protection to

\footnotetext{
${ }^{98}$ Schreuer (2007), p. 348.

${ }^{99}$ Bonnitcha et al. (2017), pp. 78-79.

${ }^{100}$ Brown and Winch (2019), p. 324, citing Centre for International Law, National University of Singapore, "Report: Survey on Obstacles to Settlement of Investor-State Disputes" (26 May 2017), pp. 11-13.

${ }^{101}$ For example, following the lobbying by Azurix Corp and Blue Ridge Investment, two investors with awards in their favour against Argentina, the US suspended trade benefits for Argentina: Bonnitcha et al. (2017), p. 81.
} 
secure compliance with an award is designed to "counterbalance any State immunity that is preserved by Art. 55". ${ }^{102}$ However, in practice, diplomatic protection has played little, if any, practical role.

\subsection{Looking Forward}

In light of the generally high rate of compliance by foreign states with investment arbitration awards, it is unlikely that any type of global reform of the rules of state immunity would be pursued. For now, it seems that it will be the responsibility of the investor to prudently navigate the different requirements under national laws necessary to ensure success in any enforcement proceedings. Many commentators have suggested that investors obtain an explicit waiver of immunity from execution from the state, such as the model clause proposed by ICSID. ${ }^{103}$ It has been noted that a waiver of immunity from execution that covers only commercial property will have little, if any, effect as, under most domestic laws, commercial property will not enjoy immunity, whereas a waiver of immunity from execution for non-commercial property is particularly important. ${ }^{104}$ It goes without saying that such a waiver will be difficult to obtain in practice, and is only likely to be relevant where the investor and the host state have entered into a contractual relationship, in which the negotiation of such a clause may be contemplated. The validity of such a waiver and the scope of property it captures will, once again, turn on the national law in force in the country where execution is sought. ${ }^{105}$ Close attention should be given to the requirements contained in such laws, particularly in light of the shifting legislative landscape governing state immunity from execution.

\section{Concluding Remarks}

While the challenge posed by a plea of state immunity from execution is not unique to the investment arbitration context, it is a useful prism through which to consider the impact of such a plea on the execution of arbitral awards resulting from investorstate disputes. In determining where to commence enforcement proceedings, awardcreditors have typically been attracted to pro-enforcement jurisdictions, which has led to a series of enforcement proceedings commenced by award-creditors, notably

\footnotetext{
${ }^{102}$ Schreuer (2007), p. 348.

${ }^{103}$ International Centre for Settlement of Investment Disputes, ICSID-Model Clauses, Section VII, "Waiver of Immunity from Execution of the Award", Clause 15 http://icsidfiles. worldbank.org/icsid/icsid/staticfiles/model-clauses-en/15.htm.

${ }^{104}$ Schreuer et al. (2009), p. 1170.

${ }^{105}$ Schreuer et al. (2009), p. 1166.
} 
in France and Belgium. The imposition of judicial measures of constraint on the assets of a foreign state has, however, had clear political consequences, prompting intervention by French and Belgian legislatures.

This chapter has considered the plea of state immunity and the execution of investment arbitration awards, and the introduction of the requirements for preliminary judicial authorisation and an express and specific waiver by Loi Sapin II and the equivalent Belgian law. A plea of state immunity from execution will continue to pose a significant hurdle for award-creditors in attachment proceedings. While the majority of states tend to comply with investment arbitration awards, in light of the experiences of award-creditors such as NML and Yukos, investors should be prudent in their approach to transacting with foreign states and remain cognisant of the national law in force in the country where execution may be sought, including any particular requirements which must be satisfied in order to successfully attach foreign state assets in satisfaction of a debt arising under an award.

\section{References}

Barten S, Krestin M (2017) "State immunity from enforcement in The Netherlands: will creditors be left empty-handed?", Kluwer Arbitration Blog, 25 April 2017

Bjorklund AK (2009) State immunity and the enforcement of investor-state arbitral awards. In: Binder $\mathrm{C}$ et al (eds) International investment law for the 21st century: essays in Honour of Christoph Schreuer. Oxford University Press, Oxford, pp 302-321

Blane A (2009) Sovereign immunity as a bar to the execution of international arbitral awards. New York Univ J Int Law Politics 41:453

Bonnitcha J, Skovgaard Poulsen LN, Waibel M (2017) Investment treaty arbitration. In: The political economy of the investment treaty regime. OSAIL, Oxford

Brown C, Winch P (2019) The confidentiality and transparency debate in commercial and investment mediation. In: Titi C, Fach Gómez K (eds) Mediation in international commercial and investment disputes, 2019. Oxford University Press, Oxford, pp 321-341

Caroit E, Daureau P, Fouret J (2015) France. In: Fouret J (ed) Enforcement of investment treaty arbitration awards: a global guide. Globe Business Publishing Ltd, London, pp 225-238

Crawford J (2019) Brownlie's principles of public international law, 9th edn. Oxford University Press, Oxford

Fox H, Webb P (2013) The law of state immunity, 3rd edn. Oxford University Press, Oxford

Franc-Menget L (2013) Vers un durcissement des conditions de renconciation à l'immunité d'exécution des Etats étrangers en droit français?, note sous Cass. civ. 1re, 28 mars 2013. Revue de l'Arbitrage 4:992

Franc-Menget L (2015) Retour au statu quo ante: Assouplissement des conditions de renonciation à l'immunité d'exécution des États concernant tous ses actifs y compris diplomatiques. Cahiers de l'arbitrage 3:505

Gaillard E (2002) Commentary. Arbitr Int 18(3):247

Gololobov D (2015) The prospect of enforcement of Hague arbitration awards against statecontrolled companies in the United States and the United Kingdom. Russian Law J III(4):7

Juratowitch B (2016) Waiver of state immunity and enforcement of arbitral awards. Asian J Int Law 6:199

Kehoe EG (2009) The enforcement of arbitral awards against foreign sovereigns - the United States. In: Bishop RD (ed) Enforcement of arbitral awards against sovereigns. JurisNet, New York, pp 241-272 
Langlois MO, Ioannou L (2016) Loosening up, but not too much: enforcement against diplomatic assets in France. IBA Arbitr News 21(1):53

Malet-Deraedt F (2018) The new French legislation on state immunities from enforcement. ASA Bull 36:332. 2/2018 (June)

Miles CS (2009) Sovereign immunity. In: Bishop RD (ed) Enforcement of arbitral awards against sovereigns. JurisNet, New York, pp 35-72

Reinisch A (2006) European Court practice concerning state immunity from enforcement measures. Eur J Int Law 17(4):803-836. 1 September 2006

Saunders M, Salomon C (2007) Enforcement of arbitral awards against states and state entities. Arbitr Int 23(3):467

Schreuer C (2007) Investment protection and international relations. In: Reinisch A, Kriebaum U (eds) The law of international relations: Liber amicorum Hanspeter Neuhold. Eleven International Publishing, The Hague, pp 345-358

Schreuer C, Malintoppi L, Reinisch A, Sinclair A (2009) The ICSID convention: a commentary, 2nd edn. Cambridge University Press, Cambridge

van den Berg AJ (1989) Recent enforcement problems under the New York and ICSID conventions. Arbitr Int 5(1):2

Phoebe Winch is a Legal Officer at the Office of International Law, within the Australian Attorney-General's Department, Canberra. Prior to this position, Phoebe practised as a Solicitor at Herbert Smith Freehills primarily in the dispute resolution team, focusing on international arbitration. She also worked as an Associate to an appellate court judge in New South Wales. Phoebe studied at the University of Sydney and has previously co-authored publications on issues of international law, including international investment law and dispute settlement.

Open Access This chapter is licensed under the terms of the Creative Commons Attribution 4.0 International License (http://creativecommons.org/licenses/by/4.0/), which permits use, sharing, adaptation, distribution and reproduction in any medium or format, as long as you give appropriate credit to the original author(s) and the source, provide a link to the Creative Commons license and indicate if changes were made.

The images or other third party material in this chapter are included in the chapter's Creative Commons license, unless indicated otherwise in a credit line to the material. If material is not included in the chapter's Creative Commons license and your intended use is not permitted by statutory regulation or exceeds the permitted use, you will need to obtain permission directly from the copyright holder.

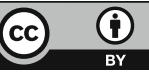

